\title{
Unilateral Multicentric Breast Cancer
}

\author{
Josip Fajdić1, Damir Buković², Damir Gugić3 ${ }^{3}$, Mario Habek ${ }^{2}$, Iva Hojsak ${ }^{2}$, \\ Nevija Buković ${ }^{4}$, Ivan Herman ${ }^{5}$ and Tajana Stančerić ${ }^{2}$ \\ ${ }^{1}$ Department of Surgery, General Hospital »Požega«, Požega, Croatia \\ 2 Department of Obstetrics and Gynecology, University Hospital Center »Zagreb«, Zagreb, \\ Croatia \\ ${ }^{3}$ Department of Oncology, University Hospital »Osijek«, Osijek, Croatia \\ ${ }^{4}$ Croatian Institute of Retirement Insurance, Zagreb, Croatia \\ ${ }^{5}$ General Hospital »Varaždin«, Varaždin, Croatia
}

\begin{abstract}
A B S T R A C T
Clinical characteristics of unilateral multicentric breast cancer (UMBC) were explored depending on aggressiveness, survival rate, disease-free period and local recurrence. The study included 296 women with breast cancer, surgically treated between 1990 and 2001. UMBC was histologically proved in 29 (9.8\%) patients. Multicentricity was defined by following criteria: a) tumor with minimum one satellite node in the same or other quadrant of the breast; b) minimum one cut through the breast without tumor cells; c) histopathologically, discontinued tumors with intra-ductal invasion. The average age of patients was 63.4 (range 36-85). There were 9 (31.0\%) women with one satellite node, 7 (24.1\%) women with two satellite nodes, and 13 (44.8\%) women with three or more satellite nodes. At the operation, axilla was positive in 20 (68.9\%) women. Steroid receptors were highly positive in $12(41.4 \%)$ patients. Primary and secondary tumors were of the same histological type in $26(89.6 \%)$ patients. Local recurrence was found in only 3 (10.3\%) patients. A five-year period without disease was achieved in $24(82.7 \%)$ women. Kaplan-Meier analysis showed a significantly higher survival rate at lower tumor stages (I or II) unlike in advanced stages with predominantly N2 grade. The results of this study showed a slightly lower five-year disease-free period than in the case of patients with monocentric breast cancer $(M O B C)$. The survival rate was significantly lower at all advanced stages, especially determined by N2 axilla. Therefore, the conclusion is that multicentricity doesn't increase the risk of poor prognosis, especially at lower tumor stages.
\end{abstract}

Key words: breast cancer, $U M B C, M O B C$

Received for publication October 21, 2003 


\section{Introduction}

Until now literature has presented a few models of multicentric breast cancer definition. That blur is sometimes caused by the term of multifocality, which is important to distinguish because of a different way of development, localization and spread.

Namely, today the established attitude of pathologists is that multifocality presents a polytopic growth of malignant cells within one duct and its branches i.e. appearance of multiple focuses of the same tumor in the same duct ${ }^{1}$.

On the other side, there are some definitions in literature for identification of UMBC:

a) gross primary tumor with minimum one satellite node;

b) histopathologically discontinued tumors with intra-ductal invasion;

c) minimum one cut between tumor through normal tissue ${ }^{2}$;

d) each additionally focus of the tumor in a different quadrant of primary tumor or in the same quadrant, but at minimally $2.3 \mathrm{~cm}$ distance ${ }^{3}$;

e) possible clonal proliferation of the solitary cancer ${ }^{4}$.

Some authors believe that the majority of multicentric tumors actually present intraductal polytopical metastases of the same lesion, which means that they are multifocal ${ }^{5}$. Obviously, the key of this problem is separation of two or more breast tumors. These attitudes differ, from the opinion according to which only one pure histological cut between two tumors is sufficient, to the one in which tumors must be localized in different breast quadrants.

The inconsistency of the problem definition is followed by a different incidence of UMBC which ranges, according to publications, from $10.3 \%$ to $65.0 \% \%^{1-3,6-11}$. According to AJCC/UICC ${ }^{12}$ accepted models of TNM classification, only the largest tumors (indexed) are considered as $\mathrm{T}$ in the multicentric form of breast cancer.

The aim of this study is to offer, based on our own experience, some answers to the dilemma of potentially higher aggressiveness of multicentric than monocentric breast cancer (MOBC), and a higher liability of local recurrence and distant metastases, survival rate etc. which is due to its clinical, biological and histopathological characteristics.

\section{Materials and Methods}

According to the retrospective analysis among totally 296 operated patients with breast cancer (various stages), 29 $(9.8 \%)$ multicentric and $14(4.7 \%)$ multifocal tumors were found. The group of patients with multicentric disease was analyzed, but the group of patients with multifocal cancer was not taken into account. The average age of patients was 63.4 (range 36-85).

The aim was to answer the following question: is the multicentric cancer significantly more aggressive than monocentric cancer in the control group of 267 patients?

The position of primary (indexed) and secondary (satellite) tumors was considered depending on different breast quadrants. The number and size of tumor were also included. It is important to mention that pathologists lacked the accurate description of the number and size of satellite tumors in some patients.

Scintimammography by the Tc- $99 \mathrm{~m}$ was not performed preoperatively, but all patients had accurate mammographic and ultrasound findings, which did not indicate multicentricity in any case. We performed breast mastectomy with axillar exenteration, without sentinel-node biopsy, after the histopathological examination proved multicentricity with free 


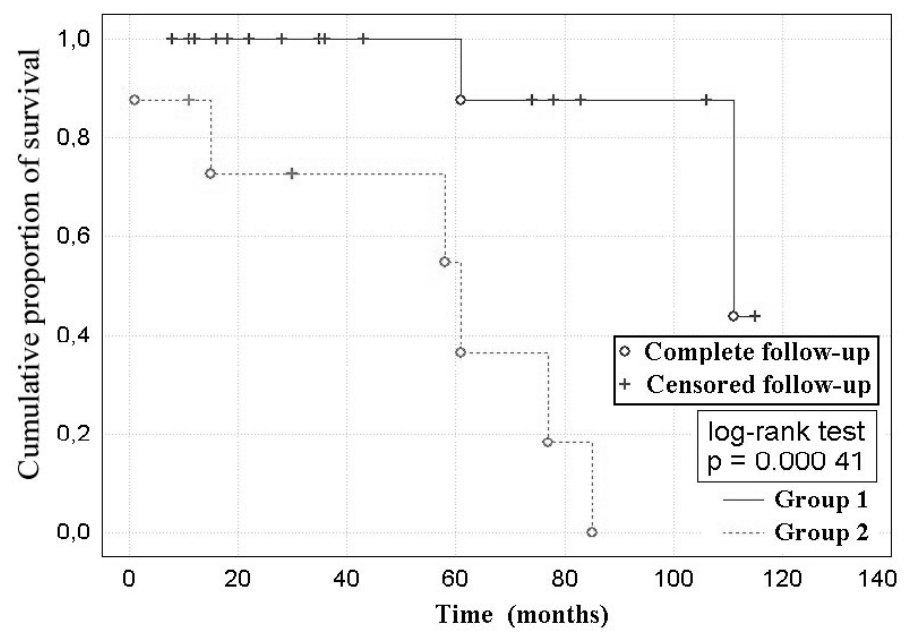

Fig. 1. Cumulative proportion of survival (Kaplan-Mayer).

margins. The removed breast was later histologically examined in total according to the standardized procedure of our pathologist. Following the description of indexed tumor, histologically suspect areas and quadrant of the breast were examined. Our criteria of multicentricity were: minimum one cut through the normal breast tissue between two or more tumors.

The follow-up was determined by the period from the time of operation to the last control examination in our Breast Center.

The adjuvant therapy by the established algorithms was preformed in two oncological centers: University Clinic for Tumors, Zagreb, and Clinical Hospital Osijek, Department of Oncology, and partially in General Hospital in Požega. The survival was evaluated by the Kaplan -Meier cumulative survival proportion (Figure 1). Hormonal dependence and histological grade of tumor according to Bloom-Richardson were tested at three levels.

\section{Results}

The average follow-up period was 6.5 years (range $0.2-12$ years). Primary tumor dimensions were $1.0-6.2 \mathrm{~cm}$, average $1.9 \mathrm{~cm}$; for some secondary tumors there were no precise descriptions in pathological findings.

Satellite nodes were found in the range from 1-6; they were localized in the same quadrant in $16(55.2 \%)$ patients and in 2 or more quadrants in $13(44.8 \%)$ patients. There were $9(31 \%)$ women with one satellite node, 7 (24.1\%) women with two satellite nodes and $13(44.8 \%)$ women with three or more satellite nodes. There were $26(89.6 \%)$ patients with identical histopathological findings of primary and secondary tumor. The histopathological type of UMBC is shown in Table 1 . The most common type was invasive ductal carcinoma $(79.3 \%)$.

The tumor appeared bilaterally in two cases. Local recurrence was found in three (10.3\%) patients. A five-year period without disease was achieved in $24(82.7 \%)$ women. There were $20(68.9 \%)$ women 
TABLE 1

HISTOPATHOLOGICAL TYPES OF UMBC

\begin{tabular}{lcc}
\hline Histopathological type & Number of cases & Percentage \\
\hline Invasive ductal carcinoma & 23 & 79.30 \\
Invasive lobular carcinoma & 2 & 6.90 \\
Mixed carcinoma & 1 & 3.45 \\
Mucionous carcinoma & 2 & 6.90 \\
Paget carcinoma & 1 & 3.45 \\
Total & 29 & 100.00 \\
\hline
\end{tabular}

with positive axillar nodes (N1-2) and 9 $(31.0 \%)$ women without metastasis in lymph nodes.

A high level of tumor hormonal dependence was noted in $12(41.4 \%)$ operated patients, out of which most were G2 grade according to Bloom-Richardson. The analyzed UMBC were mostly $(55.2 \%)$ at lower stages; I and IIA (T1-2, N0-1, M0), but $13(44.8 \%)$ patients had tumors in advanced stages; IIB, IIIa and IIIB.

The results of the surgical treatment of UMBC were best presented by the number of local recurrences in each series. There were $10 \%$ local recurrences in our sample; all of those patients were IIIA stage and died within a 5-year follow-up.

\section{Discussion}

Literature data of several protocols present UMBC incidence rate ranging from $10.3 \%$ to $65.0 \%{ }^{1-3,6-11}$, which depends on the definition of multicentricity and on the surgical sampling method ${ }^{6-11}$. There were $9.8 \%$ patients with UMBC revealed in our study.

Although the final detection of multicentric cancer is feasible by histopathological examination of breast tissue sample, the possibility of revealing the multicentricity should help us to identify the candidates for possible conservative breast surgery $^{3}$. Scintimammography Tc-99m is a powerful additional diagnostic method besides classical mammography and ultrasonography in the detection of that particular breast cancer type ${ }^{13}$. Preoperative detection of multicentricity and multifocality could significantly change the concept of treatment for several patients.

The definition of distance between primary node and satellite lesions seems disputable. According to some studies, only one cut through normal breast tissue between two tumors ${ }^{2}$ could be enough. According to other protocols, multicentricity is defined as "any additional focus in different breast quadrants or in the same quadrant, but not less than $2.5 \mathrm{~cm}$ distant from the indexed node $\ll^{3}$. There is an opinion according to which only the lesions which present in separated breast quadrants should be considered as independent tumors ${ }^{1}$.

Our attitude is that multicentric tumor is each one which is physically separated from another node by normal breast tissue, irrespective of their distance.

Our retrospective study was partly laden by insufficient description of the satellite nodes in some patients. It is important that each breast, after proven multicentricity in tissue sample, later underwent a complete, serial, histopathological examination. It means that samples were taken from all quadrants, which correspond to long ago established protocols of numerous histopathological institutes ${ }^{7,11,14,15}$. Although scintimammogra- 
phy was not performed, significant correlation between classical mammography and ultrasonography with histopathological finding of multicentricity $(75.8 \%)$ was found.

An approximately equal five-year disease-free period as in monocentric cancer was noted. The impact of several variables of survival was analyzed by Rpart modules within statistical program $\mathrm{R}^{16}$. Axillar lymph nodes involvement was the only variable ruled out by the Rpart. Thus, patients with N2 stage had a significantly worse prognosis. Kaplan-Meier rate showed a significantly lower survival rate in the group of patients with advanced stage cancer. Long rank analysis was used to show if the likelihood of difference between groups was accidental, within the interval from 0 to 1 . Thus, the difference between those two groups most likely was not accidental.

The results of our study rank us among authors who did not prove a higher aggressiveness of UMBC bearing on general survival and recurrence-free period ${ }^{9}$.

Surely, there are other results. After dissection of the whole breast, Egan verified mortality rate of $65 \%$ in UMBC patients versus only $27 \%$ mortality rate in MOBC patients stage $\mathrm{II}^{17}$. During the observed period, we proved a major axillar lymph nodes invasion by the tumor cells in UMBC patients $(68.9 \%)$ versus MOBC patients $(59.9 \%)$, which correlates with some other protocols ${ }^{1,14,18}$.

Nevertheless, if the status of axillar lymph nodes is a relevant prognostic factor in breast cancer, there is an open

\section{R E F E R E N C E S}

1. VLASTOS, G., I. T. RUBIO, N. Q. MIRZA, L. A. NEWMAN, R. AURORA, J. ALDERFER, A. U. BUZDAR, S. E. SINGLETARY, Ann. Surg. Oncol., 7 (2000) 581. - 2. WAKABAYASHI T., S. I. TSUCHIYA, G. ASANO, Breast Cancer, 2 (1995) 91. - 3. VARGAS H. I., R. V. AGBUNAG, A. KALINOWSKI, J. TOLMOS, question: why the survival rate and disease-free period in UMBC patients, despite a higher incidence of positive axilla, in our study (as in other authors) is the same as in monocentric cancer? Vlastos supposes that in UMBC groups there probably exists a synergistic combination of favorable prognostic factors (increased estrogen receptors, lower incidence of invasive ductal carcinoma etc.), which was not proved in our patients. Also, this study did not confirm a significant correlation between lobular type of breast cancer and multicentric incidence. Depending on free histopathological margins, all patients underwent modified radical mastectomy (MRM), which was also performed by the majority of authors, who consider multicentricity a contraindication for conservative breast surgery ${ }^{19-22}$.

\section{Conclusion}

According to the presented clinical, biological and histological characteristics of UMBC in 29 out of 296 patients, the results of this study have unquestionably shown that the multicentricity of the breast cancer in cases of N0-1 tumor stage does not significantly increase the risk of poor prognosis and five year disease -free period.

The cumulative proportion survival rate according to Kaplan-Meier showed extremely low survival in patients at advanced tumor stages.

A correlation between lobular and its more frequent multicentric presentation wasn't proved by this study.

S. R. KLEIN, L. DIGGLES, I. KHALKHALI, Am. Surg., 67 (2001) 1204. - 4. MIDDLETON L. P., G. VLASTOS, N. Q. MIRZA, S. EVA, A. A. SAHIN, Cancer, 94 (2000) 1910. - 5. KOYAMA, H. STRAHLENTHER, Onkol., 177 (2001) l. - 6. MCDIVITT, R. W., Breast cancer multicentricity. In: MCDIVITT, R. W., 
H. A. OBERMAN, L. OZZELLO, ET AL. (Eds.): The Breast. (Williams \& Wilkins, Baltimore 1984). - 7 . SARNELLI, R., F. SQUARTINI, Pathol. Annu., 21 (1986) 143. - 8. VAIDYA, J. S., J. J. VYAS, R. F. CHINOY, ET AL., Br. J. Cancer, 74 (1996) 820. — 9. FOWBLE, B., I. T. YEH, D. J. SCHULTZ, ET AL., Int. J. Radiol. Oncol. Biol. Phys., 27 (1993) 567. — 10. ANASTASSIADES, O., E. IAKOVOU, N. STAVRIDOU, ET AL., Am. J. Clin. Pathol., 99 (1993) 238. 11. SPINELLI, C., P. BERT, E. RICCI E, ET AL., Eur. J. Surg. Oncol., 18 (1992) 23. - 12. American Joint Committee on Cancer. Breat. In: AJCC Cancer Staging manual 5th ed. (Lippincott-Raven, Philadelphia, 1997). - 13. CWIKLA, J. B., J. R. BUSCOMBE, B. HOLLOWAY, S. P. PARBHOO, T. DAVIDSON, N. MCDERMOTT, A. J. HILSON., Nucl. Med. Commun., 22 (2001) 1287. — 14. LESSER, M. L., P. P. ROSEN, D. W. KINNE, Surgery, 91 (1982) 234. - 15.
MORGENSTERN, L., P. A. KAUFMAN, N. B. FRIED MAN, Am. J. Surg., 130 (1975) 251. - 16. THERNEAU, T. M, P. M. GRAMBSCH, Modeling survival dana. (Springer,New York, 2000). - 17. EGAN, R. L., Cancer, 49 (1982) 1123. - 18. FISHER, E. R., R. GREGARIO, C. REDMOND, Cancer, 35 (1997) 247. - 19. VOOGT, A. C., O. J. REPELAER VAN DRIEL, R. M. ROUMEN, M. A. CROMMELIN, M. W. VAN BEEK, J. W. COEBERGH, Eur. J. Surg. Oncol., 23 (1997) 134. - 20. HARTSELL, W. F., D. C. RECINE, K. L. GRIEM, M. A. COBLEIGH, T. R. WITT, A. K. Int. J. Radiat. Oncol. Biol. Phys., 30 (l) (1994) 49. 21. PRECHTEL, K. D., Geburtshilfe Frauenheilkd, 56 (1996) 184. - 22. RUDAN, N., Današnje kontroverzije s obzirom na liječenje raka dojke. Libri Oncol., 24 (1995).

\section{J. Fajdić}

Department of Surgery, General Hospital »Požega«, Osječka bb, 34000 Požega, Croatia

\section{UNILATERALNI MULTICENTRIČNI RAK DOJKE}

\section{S A Ž E T A K}

Klinička obilježja unilateralnog muticentričnog raka dojke (UMBC) su istraživana na skupini kirurški liječenih pacijentica različite dobi, pogotovo u odnosu na agresivnost bolesti, stopu preživljenja, period bez bolesti i lokalne recidive. U studiju je bilo uključeno 296 žena s rakom dojke koje su bile kirurški liječene od 1990-2001. UMBC je histopatološki dijagnosticiran u $29(9,8 \%)$ pacijentica. Multicentričnost se definira po sljedećim kriterijima: a) tumor s minimalno jednim satelitskim čvorom u istom ili različitom kvadrantu dojke; b) minimalno jedan rez kroz dojku bez tumorskih stanica; c) histopatološki diskontinuirani tumori s intraduktalnom invazijom. Prosječna dob bolesnica je bila 63,4 godine (raspon 36-85). Prosječno praćenje je bilo 6,5 godina (raspon 0,2-12). Dimenzije primarnog tumora su bile 1,0-6,2 cm, u prosijeku $1,9 \mathrm{~cm}$. Bilo je 9 $(31,0 \%)$ žena s jednim satelitskim čvorom, $7(24,1 \%)$ s dva satelitska čvora i $13(44,8 \%)$ s 3 ili više satelitskih čvorova. Na operaciji pozitivni limfni čvorovi u aksili su nađeni u $20(68,9 \%)$ žena. U $13(44,8 \%)$ žena satelitski tumori su nađeni u više kvadranata iste dojke. Steroidni receptori su bili pozitivni u $12(41,4 \%)$ pacijentica. Primarni i sekundarni tumori su bili istog histološkog tipa u $26(89,6 \%)$ bolesnica. Lokalni recidiv nađen je u $3(10,3 \%)$ pacijentica. Petogodišnje preživljenje je postignuto u $24(82,7 \%)$ bolesnice. Kaplan-Meierovom analizom je pokazano značajno duže preživljenje u nižim stadijima tumora (I ili II) za razliku od uznapredovalih stadija s N2 gradusom. Sve su pacijentice s UMBC liječene modificiranom radikalnom mastektomijom. Rezultati ove studije pokazuju niže petogodišnje preživljenje u bolesnica s UMBC nego onih s MOBC. Stopa preživljenja je bila značajno niža u svim uznapredovalim stadijima, posebno $u$ onih s N2 stadijem aksile. Zaključak je da multicentričnost ne povećava rizik za lošu prognozu, posebice u nižim stadijima bolesti. 